\title{
REORIENTASI PENDIDIKAN SEKS TERHADAP ANAK USIA REMAJA DI SEKOLAH \\ (Memadukan Sains dan Agama dalam Pembelajaran)
}

\author{
Anji Fathunaja \\ Pengasuh PA/PP Daarus Selamat Turi, Sleman, D.I. Yogyakarta
}

\begin{abstract}
Abstrak
Seks adalah kebutuhan yang secara alami melekat pada setiap manusia, tidak terkecuali para remaja. Sudah seharusnya sekolah memberikan jawaban bagi kebutuhan seksual remaja agar tidak menyimpang. Akan tetapi, sekolah saat ini hanya sebatas memberikan pengetahuan tanpa kesadaran akan nilai dan norma dalam seks. Sehingga yang terjadi adalah pelanggaran-pelangaran seks dan penyalahgunaan alat-alat keamanan seks sebagai cara aman melakukan seks. Penelitian ini berusaha untuk menemukan titik permasalahan dalam pendidikan seks yang belum mampu memberikan dampak yang signifikan pada peserta didik. Pendidikan seks yang diberikan secara terpisah-pisah menyebabkan sekat dalam pemahaman peserta didik. Pendidikan seks semestinya disampaikan secara terpadu antara agama dan sains sehingga tidak menimbulkan dikotomi pemahaman. Diharapkan setiap peserta didik tidak hanya mampu mengetahui seks (sains) namun juga menyadari nilai dan norma seks (agama).
\end{abstract}

Kata kunci: Reorientasi, Pendidikan Seks, Sekolah.

\begin{abstract}
Sex is a necessity that is naturally inherent in every human being, not even the teenagers. School is supposed to provide an answer to the sexual needs of adolescents in order not to deviate. However, the school is currently limited only to impart knowledge without awareness of the values and norms in sex. So what happens is a violation of sex-violations and misuse of security tools safe sex as a way to have sex. This study sought to find trouble spots in sex education has not been able to have a significant impact on the learner. Sex education given separately cause bulkhead in understanding learners. Sex education should be delivered in an integrated manner between religion and science so as not to cause the dichotomy of understanding. It is expected that each learner is not only able to determine the sex (science) but also aware of the values and norms of sex (religion).
\end{abstract}

Key words: Reorientation, Sex Education, Schools.

\section{Pendahuluan}

Pendidikan dewasa ini dihadapkan pada persoalan yang sulit, terutama pada pendidikan masa remaja. Masalah kenakalan remaja menjadi pekerjaan yang penting 
bagi dunia pendidikan, perlunya pendidikan yang tidak hanya mementingkan aspek kognisi tetapi juga menyoroti masalah perilaku remaja. Dalam UU RI no 20 tahun 2003 menyebutkan bahwa pendidikan adalah usaha sadar dan terencana untuk mewujudkan suasana belajar dan proses pembelajaran agar peserta didik secara aktif mengembangkan potensi dirinya untuk memiliki kekuatan spiritual keagamaan, pengendalian diri, kepribadian, kecerdasan, akhlak mulia, serta ketrampilan yang di perlukan dirinya, masyarakat, bangsa dan negara (Uyoh, 2010:5). Dari pengertian pendidikan tersebut jelas bahwa pendidikan juga harus mampu memperbaiki perilaku peserta didik.

Masa remaja berawal dari usia 11-13 tahun sampai 18-20 tahun. Freud dalam Uyoh (teori kepribadian yang menyoroti masalah dorongan seks) menafsirkan pada masa remaja sebagai sesuatu masa pencarian hidup seksual yang mempunyai bentuk yang definitif karena perpaduan hidup seksual yang banyak bentuknya (Uyoh, 2010:131). Masa remaja juga masa untuk mencari sesuatu yang di pandang bernilai, pantas dijunjung tinggi, dipuja-puji, maka pada masa ini remaja mengalami kegoncangan batin, sebab dia tidak mau lagi memakai sikap dan pedoman yang dulu tetapi dia belum menemukan pedoman yang baru (Sumadi, 1993: 234). Maka pada saat ini remaja mengalami kegoncangan yang sangat hebat, sehingga remaja sering merasa tidak tenang dan ada perasaan melawan dirinya. Pada masa ini remaja rentan terhadap pengaruh dari luar baik itu pengaruh yang positif ataupun negatif. Hal ini sesuai dengan pendapat Ericson dalam Abin yang menyatakan bahwa masa remaja adalah masa yang sangat kritis dan waktu remaja bisa menjadi the best of time dan the worst of time (Abin, 2007: 131).

Banyak pengaruh negatif yang bisa menimpa remaja misalnya masalah pornografi atau pornoaksi seks yang berakibat terjadi penyimpangan seksual yang di lakukan oleh remaja. Dalam kamus oxsford, seks berarti suatu kenyataan yang membedakan manusia masing-masing sebagai laki-laki atau perempuan (Nursyam, 2010: 18). Tetapi seks yang di maksud dalam makalah ini adalah kontak fisik atau 
hubungan persebadanan antara laki-laki dan perempuan yang dilakukan dengan sengaja baik karena imbalan atau hanya untuk mendapat kepuasan.

Berikut data penyimpangan seksual remaja dari Komisi Perlindungan Anak Indonesia (KPAI) menyatakan sebanyak 32\% remaja usia 14 hingga 18 tahun di kotakota besar di Indonesia (Jakarta, Surabaya, dan Bandung) pernah berhubungan seks (Aloenskhy, 2011). Kemudian penelitian dilakukan pada tahun 1999 oleh Sahabat Remaja, sebuah cabang LSM Perkumpulan Keluarga Berencana Indonesia (PKBI), 26\% dari 359 remaja di Yogyakarta mengaku telah melakukan hubungan seks. Menurut PKBI, 'akibat derasnya informasi yang diterima remaja dari berbagai media massa, memperbesar kemungkinan remaja melakukan praktek seksual yang tak sehat, perilaku seks pra-nikah, dengan satu atau berganti pasangan. (Bening, Mei 2004/Vol V. no.01).

Tentunya kasus tersebut sangatlah memprihatinkan, karena kasus penyimpangan seksual banyak terjadi pada usia remaja. Ditambah lagi dengan kasus yang sedang heboh diperbincangkan di televisi mengenai korban penyimpangan seks pada anak. Berdasarkan pengakuan pelaku (Emon) yang telah menyodomi puluhan anak di Sukabumi mengungkapkan bahwa anak-anak dengan sukarela menerima perlakuannya (dicabuli) dengan imbalan uang seadanya (ILC, youtube.com, 2014). Tidak cukup hanya itu saja, di Surabaya, Walikota Tri Rismaharini mengungkapkan bahwa ada seorang nenek yang masih menjadi PSK di usia lanjutnya dengan melayani anak-anak sekolah dasar (Mata Najwa, youtube.com, 2014). Maka dari itu perlulah ada peran pendidikan dalam mengatasi hal tersebut.

Salah satu upaya dunia pendidikan dalam mengatasi hal tersebut adalah dengan adanya pendidikan seks. Pendidikan seks belum menjadi mata pelajaran khusus dalam pendidikan di Indonesia saat ini. Tetapi banyak sekolah-sekolah di Indonesia yang sudah memasukan unsur pendidikan seks secara implisit pada sebagian mata pelajaran, seperti: Biologi, Pendidikan Agama dan Bimbingan Konseling. Permasalahan yang muncul adalah bagaimana cara penyampaian 
pendidikan seks agar efektif sebagai langkah pencegahan penyimpangan seks, baik sebagai pelaku maupun korban. Reorientasi pendidikan seks berupaya untuk merumuskan kembali tujuan daripada pendidikan seks untuk remaja. Berdasarkan permasalahan ini, diharapkan hasil penelitian ini mampu menambah wawasan dan khasanah keilmuan pendidikan di Indonesia serta mampu menyadarkan segenap elemen pendidikan akan pentingnya pendidikan seks.

\section{Tinjauan Pustaka}

Sebagai bahan perbandingan untuk menguatkan arah penelitian ini, berikut dikemukakan hasil-hasil penelitian yang dipandang relevan dengan permasalahan yang dikaji, yaitu sebagai berikut.

Avin Fadilla Helmi dan Ira Paramastri, Efektivitas Pendidikan Seksual Dini dalam Meningkatkan Pengetahuan Perilaku Seksual Sehat, Jurnal Psikologi UGM, No. 2 tahun 1998. Fokus penelitian ini adalah untuk menguji coba teknik yang paling efektif dalam menerapkan pendidikan seks di dalam keluarga. Hasil daripada penelitian ini adalah pendidikan seksual akan lebih efektif apabila disampaikan dengan tiga teknik, yaitu ceramah, diskusi dan brosur. Pendidikan seks dalam penelitian ini hanya sampai pada tingkat transfer of knowledge, sehingga peneliti berasumsi bahwa anak hanya akan mengetahui pengetahuan seks, namun tidak menyadari dan tetap berpotensi untuk melakukan pelanggaran atau penyimpangan seks.

Deby Yuniarti, Pengaruh Pendidikan Seks Terhadap Sikap Mengenai Seks Pranikah Pada Remaja, Fakultas Psikologi Universitas Gunadarma 2007, Penelitian ini bertujuan untuk mengetahui sejauhmana pengaruh pendidikan seks terhadap perubahan sikap remaja mengenai seks pranikah. Hasil dari penelitian ini mengungkapakan bahwa tidak ada pengaruh yang signifikan dari pendidikan seks terhadap sikap mengenai seks pranikah pada subjek penelitian. Sebelum dan sesudah diberikan pendidikan seks, sikap mengenai seks pranikah pada subjek hanya sedikit mengalami perubahan. Hal ini membuktikan bahwa model pembelajaran pendidikan 
seks di Sekolah saat ini belum bisa dikatakan berhasil dan memberikan kesadaran bagi peserta didik.

Lenci Manurung, Hubungan Pendidikan Seks Dengan Aktivitas Seksual Pada Remaja di SMA Negeri 14 Medan, Fakultas Keperawatan Universitas Sumatera Utara 2011. Hasil dari penelitian ini juga menunjukkan tidak ada hubungan yang bermakna antara pendidikan seks dengan aktivitas seksual pada remaja SMA Negeri 14 Medan. Untuk itu peserta didik perlu diberikan pendidikan seksualitas yang didalamnya terdapat program-program edukasi yang melarang remaja untuk tidak melakukan hubungan seksual pra nikah dan juga melibatkan pendidikan agama agar remaja dapat mengetahui aktivitas seksual mana yang boleh dan tidak boleh dilakukan oleh remaja.

Berdasarkan tinjauan pustaka di atas, dapat disimpulkan bahwasannya reoriontasi pendidikan seks di sekolah sangat diperlukan, agar pendidikan seks tidak kehilangan arahnya sehingga berakibat tidak mampu menjadi solusi dan pencegahan perilaku seks menyimpang. Penelitian ini lebih berfungsi untuk memperkaya penelitian sebelumnya tentang pendidikan seks bagi para remaja.

\section{Metode Penelitian}

Untuk lebih mudahnya metode penelitian ini, peneliti menggunakan sistematika sebagai berikut:

\section{Jenis Penelitian}

Penelitian ini mengacu pada data-data atau bahan-bahan tertulis berkaitan dengan topik pembahasan yang diangkat, penelitian ini masuk pada kategori penelitian kepustakaan (library research), yang merupakan suatu penelitian menggunakan buku-buku sebagai sumber datanya (Sutrisno, 1990:9). Murni dengan bahan tertulis berkaitan dengan permasalahan yang sedang diteliti. Library Research, yaitu suatu cara kerja yang bermanfaat untuk mengetahui pengetahuan ilmiah dari suatu dokumen tertentu atau berupa literatur lain yang dikemukakan oleh para ilmuwan terdahulu dan ilmuwan di masa sekarang (Masri, 1989:5). 
2. Metode Pengumpulan Data

Metode pengumpulan data yang digunakan dalam penelitian ini adalah metode dokumentasi. Metode dokumentasi merupakan metode pengumpulan data dengan jalan menganalisis data yang dibutuhkan, yaitu berupa sumber-sumber data dari beberapa literatur yang memiliki relevansi dengan tema penelitian (Suharsimi, 1998:236).

3. Data penelitian terdiri atas:

Buku-buku tentang pendidikan seks adalah data primer penelitian. Sedangkan data sekunder ini diperoleh penulis dari buku-buku penunjang maupun dokumendokumen terkait.

4. Pendekatan Penelitian

Pendekatan yang digunakan dalam penelitian ini adalah pendekatan pendidikan karena penulis meneliti dan mengkaji peristiwa yang terkait dengan perndidikan. Pendekatan ini dimaksudkan agar dapat merumuskan kembali tujuan daripada pendidikan seks sehingga relevan dengan kultur pendidikan di Indonesia

5. Analisis data

Metode analisis yang digunakan dalam penelitian ini adalah sebagai berikut:

a. Metode Analisis Deskriptif

Analisis deskriptif adalah suatu metode yang digunakan untuk menganalisis dan memberikan interpretasi terhadap data-data yang telah dikumpulkan yang kemudian dibutuhkan suatu kajian studi komparatif. Dalam model ini analisisnya adalah analisis konseptual (content analysis) atas maksa atau isi sebagaimana terkandung di dalam surat kabar atau buku (Sarjono, 2008:22). Data yang telah terkumpul dianalisis dengan cara konseptual analisis (content analysis) karena model analisis ini menekankan pada pembahasan isi yang terkandung dalam buku.

b. Metode Analisis Deduksi

Analisis Deduksi yaitu proses berfikir yang diawali dari fakta-fakta umum menuju kepada arah yang lebih khusus untuk mencari kesimpulan (Sukardi, 2009:12). Penelitian ini akan diawali dengan fakta-fakta praktek pendidikan seks di Sekolah 
dan teori-teori pendidikan seks, sehingga menemukan kesimpulan yang lebih khusus tentang tujuan pendidikan seks.

\section{Pendidikan Seks}

Pendidikan seks merupakan salah satu cara untuk mengurangi atau mencegah penyalahgunaan seks, khususnya untuk mencegah dampak-dampak negatif yang tidak diharapkan seperti kehamilan diluar nikah, penyakit menular seksual (PMS), depresi dan perasaan berdosa (Sarlito, 2004:182). Pendidikan seks lebih dari sekedar kajian tentang seksualitas manusia dalam pelajaran biologi atau sosial. Tujuan mempelajari seksualitas manusia adalah agar siswa atau anak mengetahui lebih banyak tentang seks dan tujuan pendidikan seks terhampar dibalik ini, termasuk mendorong semacam keterampilan atau kecakapan, sikap, kecenderungan, perilaku dan refleksi kritis terhadap pengalaman pribadi(J.Mark, 2006:10).

Banyak orang menganjurkan agar pendidikan anak, khususnya pendidikan seks, harus dimulai dalam dan dari keluarga. Umumnya disepakati pada masa remajalah pendidikan seks harus diperhatikan lagi. Karena pada masa ini, pertumbuhan ciri seksual sekunder mulai berkembang pesat. Dalam diri remaja mulai bergejolak perkembangan psikis dan emosional. Di satu pihak, remaja sadar bahwa mereka bukan anak kecil lagi tetapi di lain pihak, mereka juga tahu bahwa mereka belum sepenuhnya seorang dewasa (Johan, 1994:10). Akan tetapi, ada pihakpihak yang tidak setuju dengan pendidikan seks, karena dikhawatirkan dengan adanya pendidikan seks, anak-anak yang belum saatnya tahu tentang seks jadi mengetahuinya dan karena dorongan rasa keingintahuannya mereka jadi ingin mencoba.

Pandangan pro-kontra pendidikan seks ini pada hakikatnya tergantung sekali dengan bagaimana seseorang (guru/orangtua) mendefinisikan pendidikan seks itu sendiri. Jika pendidikan seks diartikan sebagai pemberian informasi mengenai seluk beluk anatomi dan proses reproduksi manusia semata ditambah dengan teknik-teknik pencegahannya (alat kontrasepsi), maka kecemasan itu memang beralasan. Sebaiknya, pendidikan seks tidak hanya penerangan tentang seks semata, akan tetapi 
juga harus mengandung pengalihan nilai-nilai dari pendidik ke subjek-didik. Dengan demikian, pendidikan seks tidak diberikan secara "telanjang" atau vulgar melainkan secara "kontekstual" (Sarlito:184).

Beberapa ciri remaja yang menonjol perlu diperhatikan oleh orang tua dan para pendidik. Umumnya remaja dilanda kegelisahan. Mereka menginginkan untuk mencari pengalaman. Mereka berusaha untuk mencoba sesuatu yang dilakukan oleh orang dewasa. Selain itu, mereka juga mulai menjelajahi lingkungan yang luas, tidak hanya lingkungan keluarga.

Berikut merupakan pendidikan seks di setiap masa-masa perkembangan seksualitas individu:

1. Masa Pra-remaja

2. Anak wanita: 11-12/ 12-13 tahun

Anak wanita mulai menemukan dirinya sendiri sebagai seorang wanita. Ia membutuhkan pendamping dalam hal penjelasan tentang menarche (haid pertama). Oleh karena itu, orang tua sebaiknya mendekati dan mendampingi putrinya walaupun tanpa mengajukan pertanyaan-pertanyaan yang dapat menimbulkan rasa malu pada putrinya.

a. Anak pria: 12-13/ 13-14 tahun

Anak pria membutuhkan pendamping, khususnya penjelasan informatif masalah mimpi basah. Dari hal ini, orangtua harus memahami masalah-masalah remaja, khususnya gejolak dorongan seksual pada masa ini mulai bergejolak secara drastis. Remaja putra mulai mencari-cari pemuasan syahwatnya melalui berbagai cara, seperti onani. Oleh karena itu, orang tua harus tetap menjaga agar remaja putra tidak melakukan hal-hal seperti itu.

3. Masa Remaja Awal: 13/14-17 tahun

Pada masa ini, remaja mengalami emosi yang selalu tidak stabil. Mereka mencari identitas diri karena statusnya di dunia tidak jelas. Pendekatan orang tua terhadap anak remaja adalah sulit karena harus menyelaraskan diri dengan gejolak masa kini. Banyak orangtua terlalu sibuk dengan karir atau pekerjaannya, sehingga kurang adanya perhatian khusus kepada anak remajanya. Padahal pada masa ini 
dorongan seks sangat menggebu-gebu, sikap nekad, berani mencoba-coba dan sembrono masih kuat tertanam di jiwa anak remaja awal tanpa mengetahui dampak buruk dari hal tersebut. Oleh karena itu, orangtua harus bersikap hati-hati untuk mensublimasi hal diatas melalui rekreasi, olahraga, pendidikan spiritual atau kesenian.

4. Masa Remaja Lanjut: 17-21 tahun

Pada masa ini, remaja ingin menonjolkan dirinya. Ia menjadi seorang yang idealis, dan mempunyai cita-cita yang tinggi. Ia berusaha untuk menampakan identitasnya. Ia cenderung tidak tergantung lagi secara emosional terhadap orangtuanya. Berhadapan dengan remaja usia ini, orangtua dan para pendidik harus mencari tindakan edukatif yang dapat memekarkan perkembangan pribadi remaja. Sikap yang baik dan bijaksana untuk diambil adalah ketika orangtua membiarkan anak untuk berdialog dan konsultasi serta rela mendengarkan pendapat mereka, saran, gagasan, dan malahan kritik dari remaja. Sikap yang salah adalah absolutisme. Banyak orangtua dan pendidik menganggap pendapat dan gagasannya adalah satusatunya yang paling benar. Pendidik memutlakkan pendapat atau gagasannya, dan menganggap bahwa dirinyalah yang harus dianggap benar (Sarlito:34-41).

\section{Pendidikan Seks di Sekolah}

Pendidikan seks secara eksplisit memang belum ada, akan tetapi pendidikan seks telah masuk dalam beberapa mata pelajaran, diantaranya biologi, agama dan Bimbingan Konseling.

\section{Mengenalkan Alat Reproduksi dalam Biologi}

Reproduksi merupakan proses menghasilkan individu baru dari organisme sebelumnya. Organisme bereproduksi melalui 2 Cara :

a) Repoduksi aseksual (vegetatif)

Adalah terbentuknya individu baru tanpa melakukan peleburan sel kelamin.

b) Reproduksi seksual (generatif)

Umumnya melibatkan persatuan sel kelamin (gamet) dari 2 individu yang berbeda jenis kelamin. 


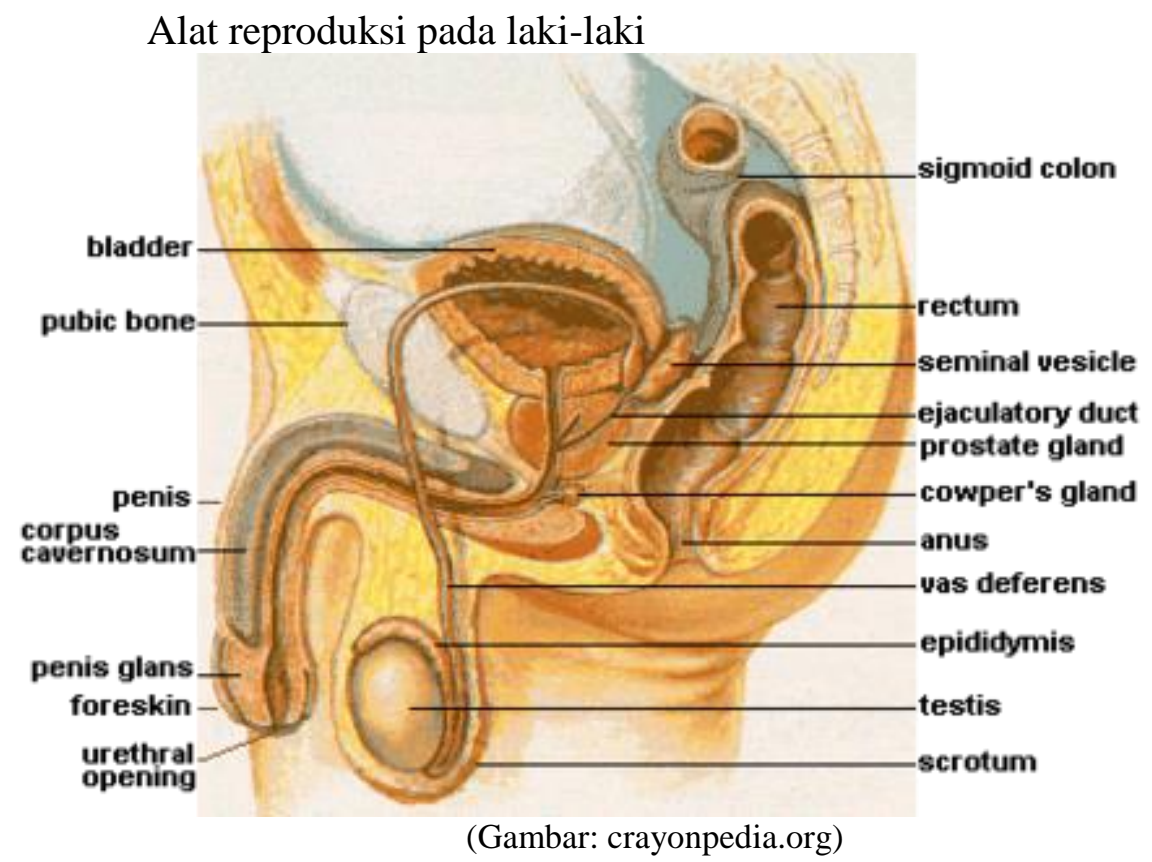

Alat reproduksi pada laki-laki terdiri atas sepasang testis, saluran-saluran kelamin, kelenjar-kelenjar tambahan, dan penis. Testis merupakan kelenjar kelamin yang berfungsi sebagiai penghasil sperma dan hormon testosteron. Testis terletak di dalam suatu kantong yang disebut skrotum. Saluran kelamin terdiri atas vasa eferentia. epididimis. dan vas deferens. Vasa eferentia merupakan bagian yang berfungsi menampung sperma untuk disalurkan ke epididimis berjumlah antara 10-20 buah. 
Sistem reproduksi pada laki-laki berhubungan erat dengan sistem ekskresi (pengeluaran), khususnya sistem urinaria. Uretra merupakan saluran yang berfungsi untuk mengeluarkan urine sekaligus sprema. Testis memproduksi jutaan setiap hari, sejak masa pubertas samapai seorang laki-laki meninggal dunia. Jika tidak dikeluarkan, sel-sel sperma akan mati dan diserap kembali.

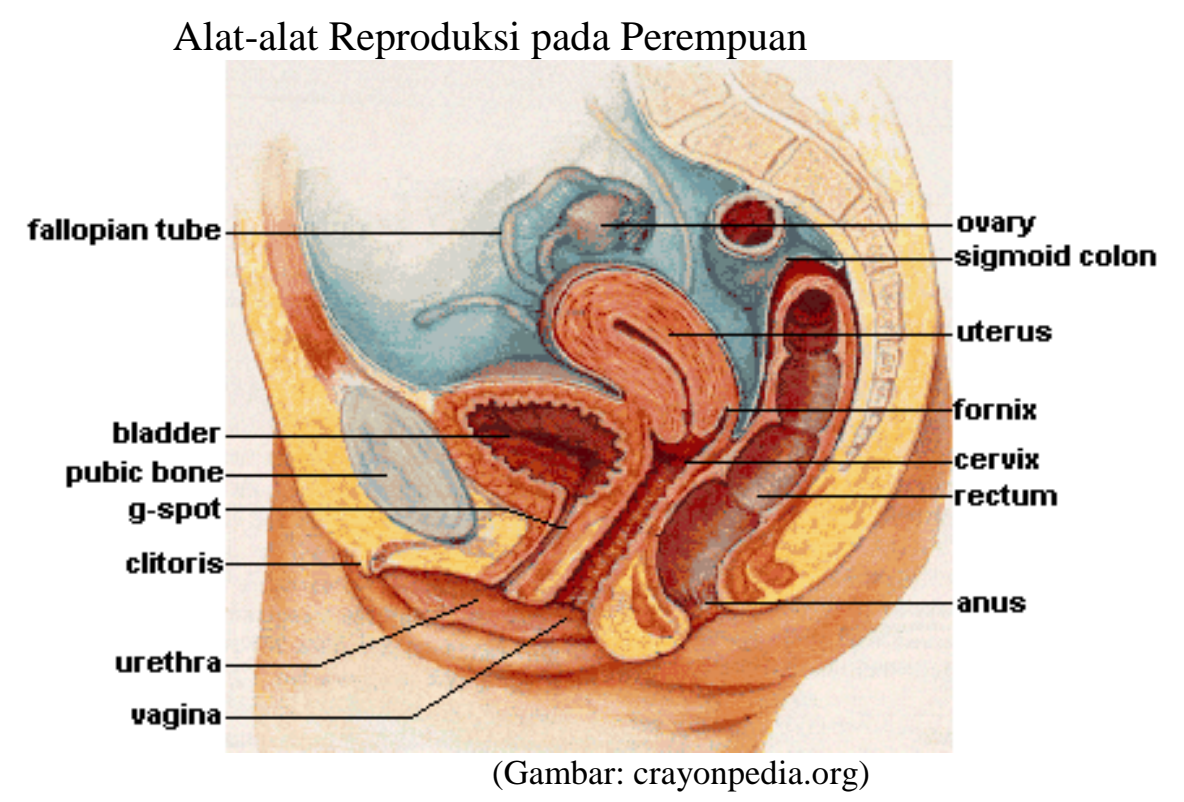

Alat reproduksi pada perempuan terdiri atas sepasang ovarium (indung telur) yang terletak di rongga perut, saluran telur (oviduk/tuba Fallopii), uterus (rahim), vagina dan organ kelamin bagian luar.

a) Ovarium merupakan kelenjar kelamin perempuan yang berfungsi untuk memproduksi ovum dan menyekresi hormon estrogen dan progesteron.

b) Saluran telur berfungsi untuk menyalurkan ovum ke arah rahim dengan gerakan peristaltik dan dibantu oleh gerakan silia yang terdapat di dindingnya. Panjang saluran ini sekitar $12 \mathrm{~cm}$ dan ujungnya berbentuk corong.

c) Uterus (rahim) berfungsi sebagai tempat berkembangnya embrio, dinding uterus tebal, panjang sekitar 7,5 cm, dan lebar sekitar $5 \mathrm{~cm}$. Selama kehamilan uterus mampu mengembang sampai 500 kali. 
Vagina merupakan saluran yang terletak di bawah uterus sebagai tempat bagi penis pada saat kopulasi dan sebagai jalan bayi pada proses persalinan.

d) Organ kelamin luar meliputi bagian-bagian sebagai berikut :

1) Klitoris (kelentit), yaitu struktur yang homolog dengan penis.

2) Vulva, terdiri atas labium mayor (bibir besar) dan labium minor (bibir kecil).

3) Lubang saluran kencing, merupakan saluran terluar uretra

4) Lubang vagina, merupakan ujung terluar vagina

5) Fundus, yaitu bagian lipat paha (Slamet\&Suhargono, $1999: 166-169$ ).

\section{Proses Pembuahan Atau Fertilisasi}

Pembuahan adalah proses peleburan antara satu sel sperma dan satu sel ovum yang sudah matang. Sebelum terjadi poses pembuahan, terjadi beberapa proses sebagai berikut. Ovum yang telah masuk akan keluar dari ovarium. Proses tersebut dinamakan ovulasi. Ovum yang telah masak tersebutakan masuk ke saluran Fallopii. Jutaan sperma harus berjalan dari vagina menuju uterus dan masuk ke saluran Fallopii. Dalam perjalanan itu, kebanyakan sperma dihancurkan oleh mukus (lendir) asa di dalam uterus dan saluran Fallopii. Di antara beberapa sel sperma yang bertahan hidup, hanya satu yang masuk menembus membran ovum. Setelah terjadi pembuahan, membran ovum segera mengeras untuk mencegah sel sperma lain masuk. Proses pembuahan ini terjadi di bagian saluran Fallopii yang paling lebar (Slamet\&Suhargo, 1999: 170).

\section{Penyakit Menular Seksual}

Penyakit menular seksual (PMS) disebut juga infeksi menular seksual (IMS) adalah penyakit yang menyebar melalui hubungan seks. PMS ditularkan melalui pertukaran cairan tubuh atau kontak seksual. Selain melalui kontak seksual, PMS juga dapat menular lewat penggunaan bersama jarum suntik dan dari ibu ke anak sebelum, selama atau setelah persalinan. PMS terutama berisiko pada mereka yang berganti-ganti pasangan. Semakin sering anda berganti pasangan, semakin besar 
risiko anda terinfeksi PMS. Resiko PMS dapat dikurangi dengan perilaku seks yang aman (Istamar, dkk, 2007: 23).

Jenis penyakit menular seksual yang selama ini terjadi di dunia ini bermacammacam, diantaranya;

1. Klamidia. Infeksi klamidia adalah salah satu PMS yang paling umum. Klamidia adalah bakteri berbentuk bola. Banyak orang yang terinfeksi klamidia tidak memiliki gejala sehingga tidak menyadarinya. Hal ini meningkatkan resiko menular ke pasangan dan berkembang kronis menjadi radang panggul. Bila timbul gejala, Klamidia dapat ditandai dengan keluarnya cairan dari penis/vagina, rasa gatal di kelamin, dan rasa sakit saat buang air kecil dan berhubungan seks. Klamidia dapat diobati dengan antibiotik.

2. Gonore (GO). Gonore adalah PMS yang disebabkan oleh bakteri. Bakteri ini menginfeksi tidak hanya organ seks, tapi juga tenggorokan atau rektum, tergantung praktik seksual yang dijalankan. Gonore bisa terjadi tanpa gejala. Bila ada, gejalanya sangat mirip dengan Klamidia. Banyak penderita gonore juga terinfeksi klamidia. Untungnya, antibiotik yang memberantas klamidia juga efektif untuk gonore .

3. Herpes genitalis. Herpes genital biasanya disebabkan oleh virus herpes simpleks (HSV) tipe II. Lesi herpes ditemukan baik di bagian luar maupun dalam alat kelamin, di sekitar anus dan rongga mulut. Tidak ada obat untuk herpes genital. Virus terus berada di dalam ganglia saraf. Dengan pertahanan tubuh yang baik, kemunculan gejala dapat ditekan. Bila sistem kekebalan tubuh buruk, infeksi dapat kambuh.

4. HIV/AIDS. AIDS adalah PMS paling berbahaya yang disebabkan infeksi HIV (human immunodeficiency virus). Virus ini hadir di semua cairan tubuh, terutama terkonsentrasi di air mani dan darah. Penularan HIV terjadi melalui kontak dengan cairan tubuh yang mengandung virus ini. Infeksi HIV/AIDS tidak bisa disembuhkan sampai saat ini, tapi diagnosis dini sangat penting. Semakin cepat 
diketahui adanya infeksi HIV, semakin terlindungi calon pasangan anda dan semakin tepat perawatan medis dapat diberikan untuk meningkatkan kualitas hidup dan memperpanjang harapan hidup pasien.

5. Kutil kelamin. Kutil kelamin disebabkan oleh virus papiloma manusia (HPV). Kutil biasanya hadir di penis atau vulva dan juga dapat terjadi di sekitar dubur atau rongga mulut. Kutil kelamin dapat diobati dengan krim khusus dan pembedahan. Beberapa vaksin yang melindungi dari kanker serviks juga dapat mencegah virus penyebab kutil kelamin.

6. Sifilis (raja singa). Sifilis disebabkan oleh bakteri Treponema pallidum. Setelah infeksi awal, bakteri menyebar melalui aliran darah ke seluruh tubuh sehingga menyebabkan ruam kulit, demam, lelah dan kehilangan rambut. Sifilis dapat diobati dengan antibiotik.

7. Hepatitis. Hepatitis B, C, D dan E dapat ditularkan melalui hubungan seksual, namun yang paling umum adalah hepatitis B dan D. Virus hepatitis menyerang liver dan dapat menyebabkan sirosis dalam jangka panjang. Meskipun tidak ada obat bagi yang sudah terinfeksi, vaksin hepatitis B tersedia untuk pencegahan hepatitis B dan D (Salma, 2011).

\section{Mimpi basah dalam Pendidikan Agama}

Setiap anak laki-laki yang sudah mengalami mimpi basah, anak tersebut sudah bisa disebut akil balig. Dengan begitu, ia sudah memiliki kewajiban penuh terhadap agama, kata Wakil Sekretaris Komisi Fatwa MUI HM Asrorun Niam Sholeh. Dengan begitu, maka semua ritual agama wajib dilaksanakan bagi anak yang sudah mengalami mimpi basah. Tapi, apa sebenarnya mimpi basah itu? Mimpi basah adalah kejadian ketika remaja bermimpi, sehingga tanpa disadarinya mengeluarkan cairan agak leng-ket dan alat kelaminnya. Cairan itu adalah air mani, campuran antara mani dan sperma. Hampir semua laki-laki mengalaminya. Karena itu. orang tua penting membuat anak merasa tenang menghadapinya. Mimpi basah sering terjadipada usia remaja. Seiring bertambahnya umur, kehadiran mimpi basah pun semakin berkurang. 
Mimpi basah adalah tanda mulai masa pubertas. Ketika anak laki-laki sudah menghasilkan sperma, ia dapat bereproduksi menghasilkan anak. Karena itu, guru agama penting menjelaskan adab bergaul dengan lawan jenisnya, mendidik seksualitas peserta didik dalam kerangka nilai-nilai agama. Sudah saatnya pula guru agama mengajak peserta didik melihat di masyarakat tentang resiko dan dampak dari pergaulan bebas.

Ketika anak pertama kali mengalami mimpi basah, hal yang harus dilakukan adalah mandi besar. Caranya, mandilah dengan diawali niat mandi besar. Disunahkan untuk wudhu dulu sebelum mandi. Baru kemudian alirkan air ke seluruh tubuh hingga bersih. Jika anak sudah mandi besar, anak sudahsah saat shalat. Karena mimpi basah merupakan perbuatan di luar kesadaran, maka jika terjadi mimpi basah saat puasa tidak akan membatalkan puasa. Walaupun tidak batal puasa, namun anak tersebut tidak boleh shalat sebelum melakukan mandi besar (Bataviase, 2012). Pelajaran agama yang cenderung bersifat normatif inilah yang berpotensi untuk menciptakan keraguan dalam diri peserta didik.

\section{Aktivitas Seksual Remaja dalam Bimbingan dan Konseling}

Aktivitas seksual adalah tindakan fisik atau mental yang menstimulasi, merangsang, dan memuaskan secara jasmaniah. Tindakan ini dilakukan sebagai bentuk ekspresi perasaan dan daya tarik seseorang kepada orang lain. Akan tetapi, dianggap menyimpang apabila tindakan ini dilakukan di luar pernikahan, karena tindakan ini dapat menimbulkan efek negatif yang dapat merugikan si pelaku. Efek negatifnya dapat dilihat dari aspek moral agamanya. Jenis-jenis aktivitas seksual pada remaja saat menjalani masa pacaran sangat beragam, mulai dari masturbasi, French kiss, hickey, necking, petting dan berujung pada intercourse (Boyke, 2012).

a. Masturbasi

Masturbasi merupakan stimulasi organ genital (seks), biasanya dengan tangan, tanpa melakukan hubungan intim. Bagi laki-laki masturbasi sering disebut juga dengan onani, dan dilakukan dengan cara mengusap-usap batang penis atau 
menggosok-gosoknya. Bagi perempuan hal ini dilakukan dengan menggesek-gesek bagian kemaluan, terutama klitoris dan vagina. Masturbasi tergolong kegiatan memuaskan diri sendiri.

Beberapa alasan dan penyebab kaum remaja melakukan masturbasi, antara lain:

1. Akibat putus cinta/ patah hati

2. Tidak berani melakukan senggama dengan pasangannya

3. Fantasi dengan tokoh yang diidamkannya

4. Kondisi keluarga yang berantakan

5. Sekedar coba-coba dan iseng

6. Pengaruh teman

7. Cari pengalaman

8. Dorongan yang memuncak akibat rangsangan dari pornografi (Marzuki:138)

Dampak negative segi kesehatan dari masturbasi kronis mempengaruhi otak dan kimia tubuh akibat kelebihan produksi hormon seks dan neurotransmiter. Meski dampaknya pada setiap orang berbeda, terlalu sering masturbasi dapat memicu gangguan kesehatan seperti kelelahan, nyeri panggul, testis sakit, atau rambut rontok. Masturbasi berkaitan dengan berkurangnya produksi testosteron dan DHT. Berkurangnya produksi testosteron juga terkait dengan kebiasaan dan gaya hidup seperti konsumsi alkohol, merokok dan berolahraga.

Jika gaya hidup cenderung normal, namun memiliki kebiasaan masturbasi sebaiknya kurangi aktivitas seksual itu untuk mengurangi keluhan. Jika keluhan tak kunjung reda, hubungi dokter untuk pemeriksaan medis (Gerry, 2012). Dampak negative dari segi moral yaitu dapat menimbulkan rasa bersalah. Rasa ini muncul dari kepercayaan bahwa orangtua mereka akan mencela hal ini karena masturbasi sangat erat berkaitan dengan stigma social (Boyke, 2012).

b. French Kiss

French kiss merupakan aktivitas yang paling sering dilakukan oleh remaja yang sedang berpacaran. Tindakan ini dilakukan dengan cara berciuman dengan bibir 
dan mulut terbuka termasuk didalamnya terdapat permainan lidah. Disebut French kiss karena orang-orang Perancis memiliki reputasi dalam hal cinta kasih.

Dampak negative dari segi kesehatan tidak terlalu bahaya, akan tetapi pada penderita penyakit menular yang terinfeksi oleh bakteri seperti sariawan dan gigi berlubang, French kiss dapat menularkan penyakit-penyakit tersebut. Dari beberapa temuan terungkap kalau riwayat pernah terkena penyakit akibat berciuman ini berkorelasi dengan risiko terkena kanker kelenjar getah bening (Hodgkin) yang mematikan.

Karena proses penyakitnya terjadi di selaput otak (meningen), ada bagian otak yang menjadi rusak. Yang sering terjadi berupa kehilangan pendengaran, gangguan belajar, kebutaan, bahkan sampai kelumpuhan.

Dari segi moral, tindakan ini adalah awal dari seluruh aktivitas amoral dalam berpacaran dan dapat menimbulkan rasa candu/ ketagihan pada setiap pelakunya. c. Hickey

Hickey adalah menghisap atau menggigit dengan gemas pasangan mereka, terkadang pada leher, buah dada, atau paha. Yang menyebabkan sebuah tanda merah atau memar.

Hickey dapat beresiko menimbulkan rangsangan yang lebih besar dibanding kissing, karena merangsang lebih dalam di bagian organ yang peka.

d. Necking

Necking adalah istilah untuk mencium bagian leher dan sekitarnya. Tindakan ini hampir sama dengan hickey, akan tetapi necking tidak sampai menghisap dan membekas merah.

e. Petting

Petting adalah langkah mendalam dari necking. Tindakan ini termasuk merasakan dan mengusap-usap tubuh pasangan., termasuk lengan, dada, buah dada, kaki, perut, dan kadang-kadang di daerah kemaluan, entah di luar atau dalam pakaian.

Baik necking atau petting sama-sama membahayakan. Sebab, persis ketika kedua pasangan kekasih memperoleh rangsangan dari tindakan ini, mereka cenderung 
terangsang dan tidak mampu mencegah untuk melakukan hubungan intim, atau tidak menggunakan alat kontrasepsi terlebih dahulu.

f. Intercourse

Lebih sering dikenal dengan hubungan intim (senggama), yakni bersatunya dua orang secara seksual intim. Dalam kasus ini, intercourse digambarkan pada pasangan belum menikah, sehingga dapat mengakibatkan dampak negatif seperti hamil di luar nikah, prostitusi, abrtus (aborsi) yang berujung pada dunia bebas atau Free Sex.

\section{Pendidikan Seks: Solusi dan Pencegahan Seks Menyimpang}

Pendidikan seks sebagai sebuah solusi semestinya mampu memberikan jalan keluar terhadap status "Darurat" pelecehan seksual di negeri ini. Pendidikan seks yang selama ini dirasakan anak di lingkungan sekolah masih jauh dari harapan dan rasa ingin tahu siswa. Siswa mempunyai keinginan melakukan seks secara alami, karena itu adalah fitrah dari Tuhan. Pendidikan seks yang terimplementasi saat ini hanya merupakan pengenalan organ-organ seksual, bentuk-bentuk pelanggaran, bahaya atau dampaknya. Sehingga anak-anak secara mandiri berusaha mencari pengetahuan lain untuk memuaskan rasa ingin tahunya. Peserta didik lebih banyak belajar tentang seks dari teman, internet dan televisi yang kering akan nilai-nilai moral. Bahaya yang disuguhkan dalam pelajaran di sekolah dapat terjawab dengan mudah, bahwa semuanya (penyakit menular seksual) bisa diatasi dengan penggunaan kondom.

Realitas pendidikan seks yang belum sebanding antara sekolah dengan dunia anak jaman sekarang dengan internet dan televisi di tangannya. Tujuan pendidikan seks yang sebenarnya untuk transfer nilai-nilai budaya bangsa kepada peserta didik belum sepenuhnya dapat diwujudkan. Hal ini disebabkan pelajaran biologi yang intens dalam mengidentifikasi organ-organ seksual terpisahkan dengan agama yang intens dalam hal aturan dan nilai. Hal ini menyebabkan keretakan pemahaman dalam diri peserta didik bahwa pendidikan seks adalah untuk memberikan kesadaran bukan 
sekedar pengetahuan. Agama yang berfungsi menyadarkan tanpa didukung biologi yang berdasarkan pengetahuan juga akan menimbulkan keraguan. Sehingga diperlukan sebuah perpaduan komplementer antara agama dan biologi sehingga mampu memberikan kesadaran akan nilai-nilai seksual dalam kehidupan.

\section{Perpaduan Agama dan Sains dalam Pendidikan Seks}

Agama dan sains sudah semestinya saling melengkapi dalam membelajarkan seks. Sains yang cenderung bersifat bebas nilai, menjadikan sains hanya sekedar menyediakan pengetahuan tentang seks semata. Sains akan memperkenalkan semua organ seks, kegunaan seks, proses reproduksi, bahaya seks menyimpang dan juga cara penanggulannya. Sains tidak menjelaskan mengenai etika, nilai dan norma yang mengikat seperti halnya agama. Agama merupakan seperangkat norma yang mampu mengikat umatnya dan memberikan ketenangan batin. Bagaimana bisa aturan agama yang tersusun dari Firman Tuhan (transendental) dapat terimplementasi dengan baik?. Tentu harus didukung dengan sains yang logic dan empiric. Sehingga agama mampu menyentuh alam pikiran yang bersifat logis dan empiris. Begitu juga dengan sains harus mampu menyentuh alam kesadaran terdalam yang mampu memberikan dampak positif terhadap tingkah laku peserta didik.

\section{Simpulan}

Pendidikan seks sekolah belum sepenuhnya mampu menjawab rasa ingin tahu remaja, sehingga yang terjadi remaja akan mencari tahu melalu internet, televisi, maupun media lain yang kurang edukatif. Sekolah sebagai sebuah lembaga yang bertugas mendewasakan remaja semestinya tidak hanya memberikan pembelajaran yang sekedar transfer of knowledge (sains), akan tetapi harus mampu trasfer of values (agama) secara terpadu. Jika dua elemen ini disampaikan secara dikotomik maka yang terjadi adalah anak menjadi liberal dengan sains dan skeptis terhadap agama. Sains yang kering akan nilai dan norma akan menjadikan anak bertindak semaunya. Sedangkan agama yang banyak memberika nilai dan norma, jika tidak dibarengi 
dengan sains yang logic-empiric hanya akan menimbulkan sikap skeptis dalam diri peserta didik. Saran untuk penelitian selanjutnya agar lebih mendalam dan fokus dalam strategi dan metode pembelajaran pendidikan seks yang memadukan antara sains dan agama, sehingga mampu menghasilkan karya yang lebih konkret lagi daripada penelitian yang sekarang ini.

\section{Daftar Pustaka}

Arikunto, Suharsimi, Prosedur Penelitian Suatu Pendekatan Praktek, Jakarta: PT. Rineka Cipta, 1998.

Avin Fadilla Helmi dan Ira Paramasti, Efektivitas Pendidikan Seksual Dini dalam Meningkatkan Pengetahuan Seksual, Yogyakarta: Jurnal Psikologi UGM, no. 2 tahun 1998.

Barta, Sumadi Surya, Psikologi Pendidikan, Jakarta: PT. Raja Grafindo Persada, 1993.

Bataviase, Mimpi Basah, Apa Itu???? www. bataviase.co.id, 03 Januari 2012.

Crayonpedia, Sistem Reproduksi dan Penyakit yang Berhubungan dengan Sistem Reproduksi Manusia, www.crayonpedia.org, 03 Januari 2012.

Indonesia Lawyers Club, Pedofil di Sekitar Kita,www.youtube.com, 14 Mei 2014.

J. Mark Halstread \& Michael Reiss, Sex Education "Nilai dalam Pendidikan Seks Bagi Remaja: Dari Prinsip Ke Praktek”, Jakarta: Yudhistira, 2006.

Manurung, Lenci, Hubungan Pendidikan Seks Dengan Aktivitas Seksual Pada Remaja di SMA Negeri 14 Medan, Medan: Fakultas Keperawatan Universitas Sumatera Utara, 2011.

Mata Najwa, Tri Risamharini Penebar Inspirasi, www.youtube.com, daiakses 14 Mei 2014.

Nursyam, Agama Pelacur, Yogyakarta: Lkis, 2010. Peng: Ridwan Nasir.

Sa'dullah, Uyoh, Pedagogik Ilmu Mendidik, Bandung: Alfabeta, 2010

Salma, Sekitar PMS, majalahkesehatan.com, 20 Desember 2011. 
Sarjono, Panduan Penulisan Skripsi, Yogyakarta: FITK UIN Sunan Kalijaga, 2008.

Sarwono, Sarlito Wirawan, Psikologi Remaja, Jakarta: PT. Raja Grafindo Persada, 2004, hal 182

Singarimbun, Masri, Metode Penelitian Survey, Jakarta: LP3ES, 1989.

Slamet dan Suhargono, Sains Biologi-2b, Jakarta: Bumi Aksara, 1999.

Sukardi, Metode Penelitian Pendidikan : Kompetensi dan Praktiknya, Jakarta: Bumi Aksara, 2009.

Sutrisno Hadi, Metodologi Research, Yogyakarta: Andi Offset, 1990.

Syamsudin Makmun, Abin, Psikologi Kependidikan, Bandung: PT. Remaja Rosdakarya. cet. 9, 2007.

Tukan, Johan Suban, Metoda Pendidikan Seks,Perkawinan, dan Keluarga, Jakarta: Erlangga. 1994.

Valentino, Yogya dan 'Hidden Culture' dalam Seks Bebas, sosbud.kompasiana.com, 21 desember 2011.

Yuniarti, Deby, Pengaruh Pendidikan Seks Terhadap Sikap Mengenai Seks Pranikah Pada Remaja, Jakarta: Fakultas Psikologi Universitas Gunadarma, 2007. 